\title{
Steder, stedsfortellinger og livsmot
}

\author{
Anne Clancy \\ Anne Clancy, professor, Ph.d., Institutt for helse- og omsorgsfag, UiT Norges \\ Arktiske Universitet, anne.clancy@uit.no
}

\begin{abstract}
\section{The vital urge to live and find meaning - stories of place}

This essay develops an understanding of how attachment to place and how physical, virtual and symbolic places can nurture or constrain a person's will to carry on and find meaning. The nursing home is presented as an illustration of a physical place and the online gaming world represents a virtual place. Young and old share stories of how the symbolic meaning of place or memories of place can nurture hope and meaning. The stories also show how their attachment to place can result in a constricted understanding of who they are. Memories of vitality and envisioning themselves as strong and active create meaning and provide a welcome distraction in their everyday lives. The author mediates with the philosophies of Levinas, Tillich and Casey in order to develop an understanding of how certain places and our understanding of them can nurture or constrain a person's will to carry on and find meaning.
\end{abstract}

\section{Keyword/Nøkkelord}

philosophies of place, Tillich, vital urge, vital force, patient stories, narratives steder, stedets filosofi, Tillich, livsmot, pasientfortellinger, narrativer

\section{Referee*}




\section{Steder, stedsfortellinger og livsmot}

Dette er et essay om livsmot og om steders betydning for å fremme eller frarøve livsmotet til unge og gamle. Jeg har gjennom forskningen min de siste årene vært opptatt av livsløpet og hvordan helse kan fremmes hos mennesker i ulike aldre. Livsmot er en nødvendig kraft som må være til stede hele livet for at mennesker skal ha det bra. Unge og gamle er faktisk, metaforisk og kronologisk på forskjellige steder i livet. Den helsefremmende tenkning legger vekt på kontekstens betydning for helse. Hensikten med teksten er å gi en dypere forståelse av hvordan steder innvirker på unge og gamles livsmot. Denne forståelsen er viktig for sykepleiere og andre helsearbeidere. Det rettes også oppmerksomhet mot hvordan andres holdninger til steder kan påvirke livsmotet.

Teksten begynner med en utlegning om hvordan livsmot kan forstås. Deretter fremlegger jeg en forståelse av steders betydning for mennesker. Teksten tar videre utgangspunkt $i$ empiriske eksempler fra egen forskning der unge og gamle har delt sine historier. Fortellingene har ulike utgangspunkt og er fra ulike steder, men har likevel til felles at de kan si noe vesentlig om hvor sterkt steder (fysiske, virtuelle og symbolske) samt kulturer på steder kan gripe inn og påvirke vårt mot til å leve. Jeg innleder ved å presentere filosofen Paul Tillichs (1886-1965) forståelse av hva livsmot kan være. Tillichs utlegninger om livsmot var en viktig inspirasjon for denne teksten. Ansvarsfilosofen Emmanuel Levinas (1906-1995) og stedsfilosofen Edward Casey (1939-) introduseres også i teksten. Levinas har lenge vært en følgesvenn i forskningen. Han skriver om det grunnleggende etiske i tilværelsen og vektlegger vårt personlige ansvar for andre mennesker. Jeg oppfatter det som et kjærkomment perspektiv i en verden preget av narsissisme og selvhevdelse. Stedsfilosofi kan gi en dypere innsikt i menneskers forhold til steder. Observasjonsstudier av sykepleiekonsultasjoner har gjort meg oppmerksom på hvordan makt og kunnskap infiltrerer steder.

\section{Hvordan forstå livsmot?}

Som leder av forskningsgruppen «Liv og livsmot» blir jeg ofte spurt om å definere hva livsmot er: «å si det med rene ord». Det er en definisjon, men det er ikke sikkert at den er beskrivende nok for hva livsmot er, eller hvordan det kommer til uttrykk. Vi kan videre bli opplyst gjennom filosofiske tekster og lese om mulige forståelser av fenomenet. Vi kan også se på hvordan livsmot kommer til uttrykk gjennom fortellinger. I denne teksten vil hverdagsfortellinger presenteres og utdypes gjennom refleksjoner sett $\mathrm{i}$ lys av filosofiske teser for å gi en dypere forståelse av livsmot.

\section{Mot til å leve}

$\AA$ A bevare liv er et etisk anliggende. Det er et prinsipp som er bærende for helseprofesjoner. Hva så med menneskets egen streben etter å bevare og fremme sitt 
liv i vanlige hverdager - også når sykdom, smerte, motgang og konflikt rammer? Paul Tillich, teolog og filosof, har vært opptatt av hva som skal til for å holde motet oppe og leve et meningsfullt liv til tross for motgang. I boken «The Courage to Be» gjennomfører Tillich (1952) en granskning av livsmot historisk og filosofisk. Han viser leseren at funderinger om livsmot kan spores tilbake til oldtiden, mytologien, legender, poesi og de greske tragediene. Han henviser til at det er en sammenheng mellom redsel for livet og redsel for døden. Tillich (1952) skriver at det ikke er døden og motgang som fratar oss livsmot, men selve «frykten» for motgang, meningsløshet og død. Et sagn fra oldtiden kan si noe om motet til å leve til tross for frykten for evig motgang og meningsløshet.

Den greske myten om Sisyfos (Camus, 1975) er som en hverdagsfortelling. Vi blir kjent med kongssønnen som på grunn av bedrageri og selvhevdelse ble dømt av gudene til å dytte en tung stein opp en bakke, for så å oppleve at steinen alltid trillet nedover igjen til utgangspunktet. Arbeidet ble gjentatt i det uendelige. Beretningen gir et bilde av et liv i oppoverbakke og kjedsomhet, mot og motløshet - en meningsløs aktivitet og monotone hverdager. Det kan være analogt til moderne menneskers kontinuerlige hverdagslige streben og handler om styrke, mot og utholdenhet. Sisyfos hadde meningsløse dager. Det vi ikke vet, er hvordan han møtte utfordringene. Hvor hentet han livsmotet fra? Vi kan tenke oss at han gikk med hodet bøyd og drømte seg bort. Det er også mulig at han gikk med løftet hode og speidet etter distraksjoner i landskapet. Slike strategier kunne avlede ham fra det meningsløse livet han levde.

Det moderne mennesket kan mene at fortellingen er irrelevant. Det er ingen mennesker som lever et slikt liv i dag. Min påstand er at myten har relevans også i dag. Våre hverdager kan være monotone, livets bakke kan av og til være bratt, byrden kan være tung, og vårt mot til å takle utfordringer kan være varierende. Beretningen kan få oss til å undre oss over hva som gir livsmot når livet er vanskelig, og når sykdom og tap rammer oss. Hvordan øyner vi håp? Leter vi etter en utvei ved å flykte av sted i drømmer og distraksjoner?

\section{Tillich og livsmot}

Tillich slår ikke fast hva livsmot er, men beskriver ulike forståelser av hva fenomenet kan være. Hans tese er at mot og frykt er sammenbundet og avhengig av hverandre. Livsmot er en kraft som opprettholder livet, og på den måten kan det sies å være både et eksistensielt og et etisk fenomen. Der det er liv, er det håp, men også angst og død (Tillich, 1952). Mot som livsvilje og frykt for døden lever side om side. Tillich argumenterer for at vi ikke kan snakke om «mot» uten å omtale «frykt». Mot vokser frem av - og til tross for - frykten.

Det kan tolkes som at det å være et menneske innebærer å ha livsmot, men samtidig leve med en evig søken etter mening og en selvgranskning som av og til resulterer i tomhet, meningsløshet og selvbebreidelse. 
Ifølge Tillich er frykt for døden, en tom og meningsløs tilværelse og selvbebreidelse de største truslene mot livsmot. Tillich (1952) fremhever betydningen av selvanerkjennelse, tilhørighet og deltakelse i verden sammen med andre som betydningsfulle for livsmot. Tillich minner oss samtidig om at vi ikke kan bestemme over livsmot; ei heller kan vi oppnå livsmot ved å bestemme oss for å inneha det. På den måten kan fenomenet betraktes som suverent. Det finnes ingen felles oppskrift for å fremme livsmot eller en universell løsning på håndtering av frykt. Jeg kan ikke bestemme meg for å elske meg selv og ha troen på at mitt liv er meningsfullt. Det er en etisk fordring å ta imot den andre (Levinas, 1969), men det er også en etisk fordring å akseptere seg selv og egen tilkortkommenhet. Våre liv er vevd sammen. Jeg har ansvar for den andre (Levinas, 1969), men er samtidig den andres andre.

Livsmot har mange uttrykk; spontanitet er ett av dem. Det kan vise seg når livets utfordringer og egen tilkortkommenhet glemmes i gode stunder på gode steder. Gode relasjoner til andre kan bidra til at det er lettere å akseptere vår egen tilkortkommenhet og opprettholde troen på at livet er meningsfullt. Det kan synes som om at kilden til livsmot er gjemt i personen selv. Den kan næres av støttende kulturer på gode steder eller tørkes ut og visne på dårlige steder. Det er ingen oppskrift på livsmot (Tillich, 1952). Livsmot er både spontant og suverent. Selv om kulturer på steder kan understøtte håp og livsmot, er det ikke i vår makt å bestemme over det.

Ut fra denne forståelsen vil jeg tolke livsmot som en spontan og suveren livsytring ${ }^{1}$. Spontane livsytringer er ikke underlagt den menneskeskapte kulturen, men kan påvirkes av den, noe som kan illustreres ved følgende anekdote: En brønn påvirkes av forhold som omgir den: I tørre perioder må det graves dypt for å nå kilden, og vannet kan være stillestående, grumsete og uklart, og i kulden kan brønnen være frossen og vanskelig tilgjengelig. I regnvær etterfylles kilden, og den kan gi fra seg vann i rikt monn; det kan drikkes, dusjes og bades uanstrengt i overfloden. Metaforisk kan denne lignelsen vise hvordan konteksten påvirker livsmotets kilde. I den videre teksten vil jeg se nærmere på steders betydning for å nære eller true vårt mot til å leve.

\section{Steder og steders betydning for livsmot}

Et sted er mer enn et rødt knappenålshode på en GPS-skjerm eller et pennemerket område på et papirkart; steder er mettet med mening (Clancy, 2016). Steder kan være fysiske, virtuelle og symbolske. Fysiske steder er

\footnotetext{
${ }^{1}$ Løgstrup skriver om de suverene livsytringer, Opgør med Kierkegaard (1968), i Etiske begreper og problemer (2014). Håp er nevnt, men ikke livsmot. Jeg tenker videre utover Løgstrup at livsmot i denne sammenheng er en suveren livsytring med påfølgende begrunnelse: Livsmot er grunnleggende og finnes hos alle mennesker, det unndrar seg oppmerksomhet, er der før kulturen og kunnskapen og er alltid til stede som potensiale. Tukler man med livsmot, går det over i sin motsats mismot. Vi kan ikke bestemme over det, og ei heller kan vi bestemme oss for å oppnå det. På den måten er livsmotet suverent. Det skal ikke alltid begrunnes eller forklares.
} 
konkrete plasser som er synlig for alle, mens virtuelle steder ikke finnes i virkeligheten, men i det fiktive virtuelle rommet. Symbolske steder er plasser som ikke er synlig for alle. Disse stedene er høyst personlige og har stor betydning for den enkelte. De er forbundet med kontinuitet, spiritualitet, trygghet og meningsfullhet (Clancy et al., 2015). Vi bærer deres betydning med oss og i oss.

Vi deltar i og betrakter verden fra vårt sted i landskapet. Våre relasjoner til steder er individuelle, og vår tilknytning til steder er en del av vår identitet. Stedstilhørighet kan påvirke hvordan du oppfattes av andre. Mitt forhold til et bestemt sted kan avsløre mine holdninger, min historie og kulturelle tilhørighet og si noe om hvem jeg er. Det er viktig å erkjenne at vi har mer inngående kjennskap til og følelser for noen steder enn for andre. Kjennskap til barndommens sted vil ikke kunne oppnås andre steder. Å erfare og ha et forhold til flere steder skjerper refleksjoner og bidrar til formulering av nye spørsmål om hva steder er og kan være (Casey, 2014). Både min barndom i Irland, et eviggrønt, frodig og fuktig sted, og mitt voksne liv i et nordlig, fjellrikt landskap med skarpt skille mellom sesongene har gitt meg en ærbødig respekt for hva steder og minner om steder betyr for mennesker.

\section{Fysiske steder}

Fysiske steder er faktiske og konkrete, og naturens landskap rommer disse stedene. Natursteder preges av værelementene. De kan være glatte eller faste, våte eller tørre, stille eller i bevegelse. Vi kan miste balansen og skade oss på et glatt sted, men samtidig oppleve en indre balanse når stedet er kjent for oss, og vi er fortrolig med dets uttrykk. Kjente steder er gjenkjennelige og gir tilsvar. Steder kan være luftige eller bakkenære. Mea på havet er kjente steder for fiskeren, likeså er luftrommet kjent for piloten. Når vi oppholder oss eller beveger oss på disse stedene, må vi tilpasse oss stedets egenart. Steder kan også være menneskeskapte, fysiske gjenkjennbare og håndgripelige steder som hus, bygninger og monumenter.

\section{Symbolske steder}

Betydningsfulle steder kan være høyst personlige og ikke gjenkjennbare for andre. Disse symbolske stedene er mettet med mening. Mitt sted kan være en bestemt plass i sofaen eller ved skrivebordet. Det kan fremkalle uro når stedet ikke lenger finnes eller er okkupert av andre. Steder kan oppfattes forskjellig. Plassen under kjøkkenbordet kan ses på som et utilgjengelig sted for rengjøring, men kan være prinsesseslottet til fireåringen som er oppslukt i sin rollelek. Stolen ved et kafébord i byen kan være et viktig hvile- og møtested for bymennesket, men være usynlig og fremmed for en tilreisende. En utbrettet pappkartong nær varmlufts kanalen i storbyen kan være et sovested for den hjemløse, men ikke 
være av betydning for renovasjonspersonalet, som betrakter det som søppel som må fjernes.

Steder gjør inntrykk og kan påvirke vår kroppslige og eksistensielle balanse. Erindringer om betydningsfulle steder kan bekrefte og forsterke hvem vi er. Gode steder kan fremkalle gode minner. Når vi hører humlen suse, lukter på syrinen, ser sommerfugler og kjenner at solen varmer, kan det fremkalle minner som tar oss tilbake i tid til lignende gode sommersteder vi bærer med oss (Clancy, 2016). Ansiktet folder seg i et smil når vi erindrer, selv om vi er langt fra disse stedene i både tid og rom. Noen steder kan gi oss gode opplevelser, men også opplevelser av skyld og skam når det ikke er kulturell aksept for at vi skal tilbringe tid der.

Vonde steder gir ikke gode minner; de er ofte knyttet til mørke, mareritt og flukttrang. Disse livsinnskrenkende stedene åpner ikke opp, men lukker ute verden og livsrommet. Å minnes disse stedene frembringer kroppslig ubehag.

\section{Virtuelle steder}

Det finnes også virtuelle steder. Disse er menneskeskapte liksomverdener vi kan få tilgang til gjennom elektroniske verktøy. Disse elektroniske stedene finnes ikke i virkeligheten. Teknologisk utstyr fungerer som et medium for å reise dit. Virtuelle steder er flyktige og labile og forsvinner ved et tastetrykk; de er til for å underholde. Casey (2014) omtaler disse flyktige stedene som «tynne steder», men skriver samtidig at de gir det postmoderne mennesket utallige valgmuligheter. Det er mulig å kople seg på virtuelle verdener gjennom deltakelse i elektroniske spill på internett. Disse virtuelle spillverdener er fremmed for mange av oss, men er kjente lekesteder for ungdommer. Det spesielle er at spillere forskjellige steder i verden koples sammen og opplever et fellesskap ved hjelp av teknologien. Medieomtale av livet til en alvorlig syk ung mann som levde et begrenset liv lenket til en rullestol (NRK, 2019), viser oss at den virtuelle verden kan være mer enn et lekested. I spillverdenen er det mulig å gjenskape seg selv og velge hvem man vil være. Mats skrev hvor mye det betydde i en blogg: «It's not a screen, it's a gateway to wherever your heart desires» (NRK, 2019).

\section{Ungdom og virtuelle steder}

Ungdommene befinner seg på et fysisk sted. Det kan være et mørkt, rotete soverom med uoppredd seng og gulvet fullt av sammensurrete ledninger, kabler og tomme pizzaesker. Stedet kan også være et ryddig, tomt kontor. I denne sammenhengen er ikke det fysiske stedet viktig - lyset er ofte dempet. Den spillende snur ryggen til oppholdsrommet og er vendt mot et virtuelt verdensrom. Det teknologiske utstyret er viktig. Gjennom teknologiens virkemidler møtes deltakerne online. Ved en villighet til å følge spillets regler transporteres 
de til et virtuelt sted uten fysisk forflytning. Spilleren får en gruppetilhørighet som medlem av et team og må samarbeide med andre for å løse oppgaver. Mange av online-spillene er kampspill, og det utdeles poeng, belønning og forfremmelse for oppnådde resultater.

I forbindelse med et forskningsprosjekt snakket jeg med ungdommer om deres forhold til og opplevelser med å delta i en virtuell spillverden (Arvola \& Clancy, 2014; Clancy, Arvola \& Gurgens, 2015). Denne verdenen er ukjent for mange voksne. En av ungdommene, Tom, fortalte følgende om den mytiske virtuelle verden av Azeroth ${ }^{2}$ :

«De utallige byene du finner i spillet, er så tett på virkeligheten at de fornemmes som ekte. Du finner vanlige dagligvarebutikker, du kan få skjorter fra en skredder, rustning fra en laeremester eller en ny $\phi k s$ fra den lokale smeden. Spillet har også rollespill som fokuserer på å skape en virtuell verden ved å engasjere oss $i$ aktiviteter som å gå på puber, gå på tur med andre, og du kan til og med gifte deg med en annen virtuell spiller. For å bidra til følelsen av en annen verden er det flere arrangementer / festligheter som følger kalenderåret. Det er for eksempel en 'midtsommerfestival' og en 'olfestival' som spillerne kan delta i.»(Clancy et al., 2015:12).

De unge guttene fortalte om sine opplevelser. Det som er spesielt med disse virtuelle kunstige stedene, er at selv om rammene er lagt og må følges, kan deltakerne styre hvilken rolle de skal ha, og de bestemmer hvem de vil være. Dyktighet i rollen avgjøres av tekniske ferdigheter, men også av hvordan spilleren presenterer seg selv. Noen ungdommer beskrev hvordan de opplevde å tape på skolen og føle seg mislykket. De fortalte om meningsløse aktiviteter, men i spillverdenen fikk de anledning til å være en sterk, vellykket rollefigur. Som en sa: «Du kan fly om du vil». En annen beskrev det som en flukt: «Så vil man kompensere for ting man ikke får til i den virkelige verden» (utdrag fra intervjutekstene) (Arvola \& Clancy, 2014).

Disse spillene er sosiale og konkurransepregete. Ungdommene fortalte om fordelene ved å spille og om gleden ved å være en del av et fellesskap. De fortalte også om opplevelser av skam og skyld over å bruke tid på noe som ikke var kulturelt akseptert, og som ble betraktet som bortkastet tid (Arvola \& Clancy, 2014; Clancy et al., 2015). Etter timer med spilling kunne guttene oppleve bebreidelse fra foreldre og venner og selv sitte igjen med skyldfølelse for å ha kastet bort tiden på en meningsløs aktivitet. Denne tiden kunne de ha brukt på skolearbeid eller hjelp i hjemmet, eller de kunne ha vært sammen med familie, kjæreste eller venner.

\footnotetext{
${ }^{2}$ Azeroth er en virtuell verden i spillet «World of Warcraft» - Massively Multiplayer Online Role-Playing Games (MMORPG)
} 
En gutt fortalte: «For det første så tror jeg at vi som spiller har veldig dårlig samvittighet fordi det på en måte er tid man har brukt som man kunne ha brukt på noe mer produktivt (...). Det er mange som sier det samme.» En annen sa at «generelt så ser folk negativt på dataspill». Han snakket videre om hans foreldres negative holdning og at han syntes det var urettferdig at de uttalte seg om noe de ikke forsto (Clancy et al., 2015:13-14).

Ungdommene fortalte også at i noen kretser ga det status å spille internettspill. En gutt hadde oppnådd internasjonal status $\mathrm{i}$ et online spillmiljø og sa at han syntes det var gøy å være best i noe. Han fortalte at hans dyktighet i spill ikke ble anerkjent i hverdagen.

Ungdommenes opplevelser viser at å være i det virtuelle landskapet ga glede, men andres oppfatninger av deres opphold der ga grobunn for negative følelser. Vårt velbefinnende påvirkes av våre omgivelser (Casey, 1998), men også av andres oppfatninger av oss sett i lys av de stedene vi oppholder oss.

De foregående beskrivelsene av stedstyper og ungdommenes beretninger om den virtuelle verdenen kan gi en forståelse for hvordan ulike steder og oppfatninger av steder kan påvirke vårt livsmot. Steder kan være rom vi søker tilflukt i, men også plasser vi vil rømme fra. I de følgende avsnittet vil jeg ta kvantespranget til sykehjemmet, som er et fysisk sted for eldre mennesker.

\section{Sykehjemmet som sted}

Dagens gamle opplevde ikke virtuelle spillverdener som unge. Erfaringer fra sykehjemmet kan formidle andre typer stedserfaringer. Selv om stedstype, alder og kultur er vesentlig forskjellig fra ungdommenes steder, må de gamle også tåle motgang og forholde seg til monotone hverdager. Å være syk og gammel kan innebære å måtte flytte til en institusjon - et sykehjem. Sykehjemmet kan være milevis fra et kjent sted. Den gamles helsetilstand samt rommets utforming kan begrense muligheten for fysisk bevegelse innendørs.

I et forskningsprosjekt knyttet til fallforebygging og velbefinnende på sykehjemmet (Clancy et al., 2015; Clancy \& Mahler, 2016) ble pleiere og pasienter intervjuet. Det ble også foretatt observasjoner på stedet. Hvordan vi organiserer fysiske rom, omgivelsene og de tingene vi omgir oss med, kan ha innvirkning på vårt velbefinnende. Stedets arkitektur ble fremhevet som viktig av pleierne. De fortalte om utfordringer knyttet til sykehjemmets fysiske utforming. Trange ganger og dårlig plass kunne gjøre det vanskelig for beboerne å bruke rullator eller rullestol (Clancy \& Mahler, 2016). Selv om pleierne gjorde så godt de kunne for å tilrettelegge omgivelsene, kunne sykehjemmets fysiske utforming og pasientenes begrensete mobilitet gjøre det vanskelig å håndtere hjelpemidler i trange ganger. Disse forholdene kunne $\varnothing \mathrm{ke}$ frustrasjonsnivået og til og med 
skape konflikter med andre beboere, noe som kunne bli en trussel mot de gamles verdighet og integritet, og skape en opplevelse av mislykkethet.

Den kritiske sosiologen Hermut Rosa minner oss om at vi må være oppmerksomme på strukturer relatert til tid og rom, fordi disse gjør noe med vår væren i verden (Rosa, 2010:42). De gamle fortalte ikke så mye konkret om sykehjemmet som sted. De var mer opptatt av fortellinger fra andre steder og tider som kunne være identitetsstyrkende og si mer om hvem de var og ønsket å være.

Jeg snakket med noen mannlige pasienter. De fortalte om sykdommers begrensninger og utfordringer med å finne mening i tilværelsen. Mennene var klar over at de var avhengig av hjelp, men ville også formidle at de hadde levd lange liv og var noe mer enn skrøpelige gamle kropper (Clancy \& Mahler, 2016). De fortalte historier fra yngre dager da de var virksomme og engasjert i aktiviteter. Deres fortellinger fra fortiden var forbundet med arbeid, styrke, potens og overskudd (Clancy et al., 2015). ^ minnes ungdomstiden og betydningsfulle steder så ut til å tenne en livsgnist, selv om fortellingene var forbundet med arbeid og slit. Tankereiser til gode steder formidlet gjennom fortellinger ga fysiske utslag. Den gamle fiskeren som var dårlig til bens, reiste seg forsiktig opp og demonstrerte hvordan han som ung balanserte om bord i en båt i brottsjø. Verkstedarbeideren fortalte at han hoppet fra bjelke til bjelke i en båt fylt av tykk svart røyk. Når han fortalte, ble han opprømt og ivrig. Oksygenmasken ble fjernet, og det var tydelig at minner om mot og utholdenhet ga styrke og fortellerlyst. Han fortalte: «Når vi begynte å skjare med skjarebrenneren $i$ blymønje, så var det jo røyk uten like.(...). Det var så mye røyk at jeg ikke så noen ting. Jeg skulle ikke ha funnet døren. Og på toppen av det hele, så hadde dem revet gulvet, så jeg måtte hoppe på bjelkene. Fy $f^{* *}$ hva man har vart utsatt for mange ganger» (Clancy et al., 2015:6).

En annen pasient lå utstrakt på senga og fortalte om hverdagen sin, som han følte var meningsløs. Han fortalte videre om tiden som ung, om sommerarbeid og aktiviteter i øyriket i Nord-Norge, om kvinnebes $\varnothing \mathrm{k}$ på $\varnothing$ yene og hvordan han slo mål etter mål med ljå ute på holmer i havgapet. «Men ae arbeidde jo, slo jo et jorde her en gang, 25 mål (...). Det va jo 40-50 kvinnfolk som kom om sommarn og arbeidde, la ut klippfisk til tørk utover bergan»(Clancy et al., 2015:6). Sengeliggende snakket han om muligheten for å være virksom og delta i sykehjemmets aktiviteter.

Besøkene på disse sykehjemmene samt pasientenes og pleiernes fortellinger gjorde inntrykk. Det ga meg en forståelse for de gamles behov for pleie og omsorg, men også for deres behov for å ta seg fri fra dagens strev og foreta tankereiser til betydningsfulle steder for å hente styrke og finne mening. 


\section{Selvbebreidelse og meningsløshet som trusler mot livsmot}

Både de unges og de gamles fortellinger viser at livsmotet kan svekkes når vi møter motgang og livet oppleves som meningsløst. De unge bebreidet seg selv for overdreven spilling. «Selvbebreidelse» og opplevelse av «meningsløshet» kan true vårt mot til å leve (Tillich, 1952). Både unge og gamle hentet styrke ved å ta seg fri fra dagens strev. Fellesskap med andre likesinnede i en online-verden var viktig for de unge og var en vesentlig grunn at de tilbragte tid der. De gamle søkte tilflukt i minner fra tidligere i livet. $\AA$ minnes gamle dager og fortelle om seg selv som sterke og vitale gjorde godt for sykehjemsbeboerne. De gamle erindret styrke, og de unge spilte sterke. Denne vitaliteten så ut til å fremme livsmot. Mot er sinnets styrke til å takle motgang; mot beskytter liv (Tillich, 1952). Vitalitet kan forstås som et uttrykk for livsmot (Tillich, 1952).

Selv om å tilbringe tid i en spillverden, å lykkes i kampspill eller å mimre om gamle dager kan betegnes som bortkastet tid av enkelte, kan disse aktivitetene gi livsmot for de det gjelder. Dermed er de betydningsfulle. Selv om total frikopling fra livet ikke er mulig, kan slike aktiviteter gi oss en bekreftelse på egenverd uansett alder. Noen av ungdommenes fortellinger bærer preg av skyldfølelse på grunn av negative tilbakemeldinger. Skyldfølelse og skam er lenket sammen, og skammen tar plass når vi vet at vår atferd ikke aksepteres av andre; vi kan bli dommer over og samtidig fanget av våre egne handlinger (Levinas, 2003).

Ungdommenes flukt i den virtuelle verdenen er tidsbegrenset. Når ungdommen snur kroppen vekk fra dataskjermen, gjenoppstår rommet i synsfeltet. Frihetens øyeblikk er over, og etisk selvgranskning og mismot kan komme snikende tilbake. Det kan gi et forsterket behov for å flykte. Levinas (2003) skriver om behovet for flukt, men advarer samtidig mot idolisering av steder, da opplevelsen av glede kan bli kortvarig. Ifølge Levinas er det i relasjoner og gjennom andres velbefinnende at vi opplever ekte glede (Levinas, 2003).

\section{Opplevelser av mot og styrke understøtter livsmot}

De eldre personene jeg intervjuet, var avhengig av hjelp og trengte pleie og tilsyn. Hverdagen deres var preget av alderdommens og sykdommens begrensninger. De trengte også å overskride hverdagens trange rom. Mennene var opptatt av å fortelle om seg selv som unge og sterke. De ble oppstemte da de fortalte om gamle dager, enten det var på havet, på en holme eller i et skipsverft. Disse stedene var gjenkjennbare og hadde stor betydning selv mange år etterpå. Gjennom å fortelle om det fikk de frem en opplevelse av egenverd. Det gjorde godt å være tilbake på steder der de kunne være sterke og vitale.

Ifølge Tillich (1952) er selvbekreftelse og fellesskap med andre viktig for å holde meningsløshet og selvbebreidelse på avstand. For å finne mening søker mennesker noe som er større enn deres faktiske og konkrete hverdagseksistens 
(Levinas, 2003). Vi trenger fristeder for å hente krefter og beholde viljen til å leve til tross for motgang. Levinas (2003) tematiserer menneskers muligheter til å kople seg fri fra værens lenker og skriver at flukttrangen kan være utløst av et behov for å komme vekk fra seg selv (Levinas, 2003). Mennesker har behov for å være på steder der egne begrensninger ikke spiller noen rolle. Gameren Mats skrev: «Mine lenker er brutt, og jeg kan velge hvem jeg vil vare» (NRK, 2019). Spillende ungdom kan oppleve at de ikke strekker til. Deres identitet er slått fast med deres atferd som gamere. Det kan være fristende for dem å tilbringe tid i en virtuell verden der de får anerkjennelse og lykkes.

Gjennom å foreta tankereiser og fortelle om minner kan de gamle føle seg virksomme, vitale og verdifulle. Å oppleve forskjellige sider av seg selv og få bekreftelse fra andre kan være en motkraft til opplevelser av tomhet. A ha noen å dele opplevelser med er viktig. Verken den virtuelle spillverdenen eller minneverdenen er faktiske steder, men et opphold der kan gi næring, underst $\varnothing t t e$ livsmot og gi styrke til å møte dagens utfordringer. Selvbekreftelse til tross for egen tilkortkommenhet er betydningsfullt for livsmot (Tillich, 1952).

$\AA ̊$ vite hvor en person tilbringer tid, kan si noe om han er lik oss eller ikke. Det trekkes ofte konklusjoner om hvem mennesker er og hvordan de skal forstås ut fra en generell forståelse av aldersgrupper, steder og kulturer. Det konkluderes med viten om gruppens verdier, status og behov. Medieomtalen av Mats er et godt eksempel. Han ble sett på som isolert uten mulighet til å få venner og leve et rikt liv. Han var lenket fast til en rullestol med begrenset bevegelighet (NRK, 2019). Foreldrene var fortvilet over hans livssituasjon og tidsbruk på nettet. Det de ikke visste, var at i den virtuelle verdenen var han kvinneforfører, en detektiv og en rask løper. Han var en viktig person for flokken sin. Sykdommen spilte ingen rolle. Det var først da Mats var død at foreldrene oppdaget hvordan gaming hadde gitt ham en mulighet til å velge hvem han ville være, og overskride sin tilværelse i den virkelige verden.

For å leve et godt liv kan vi ha behov for flere identiteter (Levinas, 1969). Vi er oss selv, vi er ikke oss selv. Vi er barn, vi er ungdommer, vi er voksne. Vi er lekne, vi er seriøse. Vi er betydningsfulle her, men ikke like betydningsfulle der. Den unge er ikke bare en taper - en uansvarlig gamer. Han er også den ansvarsfulle som har betydning i et fellesskap på internett. Den gamle er mer enn en hjelpetrengende sykehjemsbeboer. Han har levd et helt liv og er også barn, ungdom, sveiser, fisker, kvinnebedårer og venn.

Det kan svekke livsmotet å ha tilhold et sted der vi speiles gjennom blikket til mennesker som har en begrenset forståelse av hvem vi er: ung og spill avhengig, gammel og syk, den som står opp om natta, den som ikke står opp om morgenen, eller den som ikke har venner. Fordringen om å elske seg selv kan være vanskelig å møte på slike steder. Å utvide forståelsen av hvordan vi oppfatter oss selv og 
hvordan vi forstår andre, kan være et godt utgangspunkt for å understøtte eget og andres livsmot. Menneskers mange sider må forstås. Den gamle har levd et langt liv og har sine minner. Disse gir tilgang til gode opplevelser fra personlige steder med stor symbolsk betydning. Den unge må gis mulighet til å drømme, skape minner og tegne bilder av en fremtid som gir livslyst. Det er fellesskapet, opplevelsen av å vinne og være betydningsfull samt det å ha et tilfluktssted som gjør spillverdenen attraktiv. Vi som er foreldre til ungdommer eller jobber med ungdommer, må forstå vårt ansvar og se betydningen av å legge til rette for disse opplevelsene i den virkelige verden.

\section{Noen avsluttende tanker}

Livsmot kan komme til uttrykk som en tro på livet som er stor nok til å absorbere motgang, meningsløshet og eksistensiell frykt. Innledningsvis henviste jeg til Sisyfos og skrev at vi ikke vet inngående hvordan denne mytiske figuren taklet meningsløsheten, og ei heller hvordan han næret livsmotet $i$ en absurd tilværelse. Det kan være at han drømte seg bort og tenkte på en lystig fortid, eller speidet etter mulige distraksjoner i landskapet. Vi har sett for oss en enslig figur med en kolossal byrde. Kanskje var han ikke alene på ferden, men deltok i et støttende fellesskap av steindyttende helter.

Etter å ha reflektert over fortellingene til unge og gamle fornemmer jeg at tilfluktsteder, gode relasjoner med andre og en utvidet forståelse av seg selv som vital kan gi en opplevelse av egenverd. Det har vist meg at det er mulig å overskride trange rom, og at vi ofte vet for lite om hvem eller hva som er viktig i andres liv. Vi kan ikke bestemme over livsmot, men det er i vår makt å bekrefte og støtte andre. Når gamle mennesker forteller om tidligere tider og ungdommer snakker om gaming-opplevelser, er det fordi det er viktig for dem. Å bli anerkjent og tatt på alvor kan være identitetsskapende for den unge og identitetsstyrkende for den gamle. De får bekreftet sitt egenverd og kan få fornyet livsmot til å takle hverdagens krav.

\section{Litteratur}

Arvola, A.K.P. \& Clancy, A. (2014). World of Warcraft - til ungdommers begjær og foreldres besvær. Unge online-spillende menns opplevelse av samspillet med foreldre og medspillere. Fokus på familien, 3, 184-203. Oslo: Universitetsforlaget.

Camus, A. (1975). The myth of Sisyphus. London: Penguin books.

Casey, E. (2014). Body Self and Landscape, A Geophilosophical Inquiry into the Place-World. Hentet fra https://philosophydocuments.files.wordpress.com/2014/11/22-bodyself-landscape.pdf Nedlastet 19. januar 2018.

Casey, E. (1998). The Fate of Place A Philosophical History. Berkeley: University of California Press. 
Clancy, A., Arvola, A.K.P. \& Gjærum, R.G. (2015). Moral responsibility is never a spectator sport: On young people and online gaming. Journal of Applied Arts \& Health, 6(1), 7-21.

DOI: https://doi.org/10.1386/jaah.6.1.7_1

Clancy, A., Balteskard, B., Perander, P. \& Mahler, M. (2015). Older persons' narrations on falls and falling -Stories of courage and endurance. International Journal of Qualitative Studies on Health and Well-Being, 10(1). DOI: $10.3402 / \mathrm{ghw} . \mathrm{v} 10.26123$

Clancy, A. \& Mahler, M. (2016). Nursing staffs' attentiveness to older adults falling in residential care - an interview study. Journal of Clinical Nursing, 25(9-10), 1405-1415. DOI: 10.1111/jocn.13240. 2016.

Clancy, A. (2016). Steder rommer elementene. Det nordlige mennesket og stedets betydning for helse og velbefinnende. I B. Stenbock-Hult \& A. Sarvimäki (Red.), Healthy Ageing, Nordiska perspektiv på äldre hälsa och främjande av äldres hälsa. Arcada Working Papers. Hentet fra http://dspace.arcada.fi:8080/xmlui/bitstream/handle/123456789/39/AW P_2-2016_Healthy\%20Ageing.pdf?sequence $=1 \&$ isAllowed $=y$ Lastet ned i januar 2018.

Levinas, E. (1969). Totality and infinity / an essay on exteriority. Pittsburgh, Pa.: Duquesne University Press.

Lévinas, E. (2003). On escape: De l'évasion. Stanford, Calif.: Stanford University Press.

NRK.no (2019). Fфrst da Mats var d $\phi d$, forsto foreldrene verdien av gamingen hans. Hentet fra https://www.nrk.no/dokumentar/xl/forst-da-mats-vardod_forsto-foreldrene-verdien-av-gamingen-hans-1.14197198. Lastet ned 7. februar 2019.

Rosa H. (2010). Alienation and Acceleration: Towards a Critical Theory of Late -Modern temporality. Aarhus: University Press.

Tillich, P. (1952). The Courage to be. New York: Vail-Ballou Press, Inc. Hentet fra

http://www.pols.com/Research_files/Source\%20Material/Tillich/courag eofbe011129mbp.pdf. Lastet ned 20. desember 2018. 